\title{
Nurturing Learners' Awareness of Littering through Environmental Campaigns: An Action Research Approach
}

\author{
Tomé Awshar Mapotse \\ University of South Africa, SOUTH AFRICA \\ Tsebo Kgoto Mashiloane \\ University of South Africa, SOUTH AFRICA
}

Received 11 March 2017 • Revised 29 June 2017 • Accepted 24 August 2017

\begin{abstract}
The availability and accessibility of disposable items has contributed immensely to our littering behaviour as humans. People discard plastic containers, paper wrappers and other items by throwing them onto the ground, thus aggravating the problem of littering. This study aims to assist the relevant stakeholders in integrating environmental awareness activities into the school curriculum, to drastically reduce littering in communities. Underpinned by developmental action theory and applied participatory paradigms, the study purports to assess the success of environmental action research campaigns aimed at combatting littering. Fourteen learners from seven classes served as co-researchers, having been randomly selected as participants in this study. Participants' observations and pictures were used to collect data, before resorting to coding and analysis. The results of the study show an improvement in learners' awareness of littering, allowing the authors to conclude that action research, if employed in environmental education, can raise learners' awareness pertaining to littering. A lack of environmental programmes in schools is also to blame for the fact that children often unwittingly litter or pollute their environment.
\end{abstract}

Keywords: environmental education, action research, developmental action theory, littering

\section{INTRODUCTION}

Learners in the case studied school consume different foodstuffs on a daily basis. These foodstuffs are bought at school tuck shop, from fellow learners and vendors, and others bring their lunch bag. Their foodstuffs can be categorised into four, namely, fruits, snacks, drinks, and fast food. Food items bought by learners are covered by plastic bags and that was the reason learners littered on the school premises (Msezane \& Mudau, 2014). In addition, the school-feeding scheme has their own menus offered on different days and learners tend to toss food remains on the ground. When the researchers asked some of the learners why they threw food on the ground they indicated as follows, "The food was tasteless", "porridge with fresh milk not edible". Learners who lamented that the food was not properly cooked threw a considerable amount of food away (Silo, 2011). Moreover, learners use obscured parts of school buildings as hideaways for smoking and dropping cigarette butts on the ground, which contributes to littering. The case studied school over the years learner population has increased. This increase most likely did not change learners' littering behaviour.

(C) Authors. Terms and conditions of Creative Commons Attribution 4.0 International (CC BY 4.0) apply. Correspondence: Tomé Awshar Mapotse, University of South Africa. 


\section{State of the literature}

- Literature suggests that despite so many countries embarking on environmental campaigns the environmental pollution is far from over.

- Environmental education should be taught at both home and school environment to raise environmental literacy and awareness.

- All schools' stakeholders should take a lead in empowering their learners and staff about the health benefit of learning within a clean environment.

\section{Contribution of this paper to the literature}

- Developmental theory has reinforced cooperation, bind people together for a common goal of promoting Environmental Education, and facilitate a relationship of trust to all role players.

- Environmental action research has proven to be a better approach to conduct Environmental Education within a school set up which will then affect learners to consciously take care of their home and communities.

- The study has the potential to inspire other environmental educationists to aspire to embark on action research with their participants, so that littering will be a story of the past and cleanliness will end up being a lifestyle.

As such, the integration of the subject Environmental Education (EE) into the school curriculum is intended to impart environmental knowledge to society at large, starting with school-going children. EE is a crosscurricular discipline which edifies society about the environment and related issues. In turn, members of an environmentally literate society are bound to consider their impact on the environment, prior to taking any action. Budvytyte (2011: 27) states that EE is crucial in shaping an eco-culture amongst youth, because a literate human is a responsible human. However, the availability and accessibility of disposable items has contributed enormously to littering behaviours. Litter is a growing problem in South Africa (Mambinja, 2008: 10) because of modernisation e.g. pollution from industries (Le Grange, 2003). People in particular learners discard plastics, paper or foil wrappers, tins, peels and pips and other items by tossing them onto the ground, thereby polluting their environment.

The following scholars Komane (2005) and, Sethusha and Lumadi (2013), states that much of the environmental degradation that occurs today is primarily a result of failure of our society and educational systems to provide citizens with the basic understanding and skills needed to make informed choices about the interactions and interrelationships with the environment. Owing to the challenge for education systems is how to engage learners so that they become environmentally literate. This study sheds light on a progressive environmental action research (PEAR) campaign which stakeholders can use to integrate activities aimed at combatting littering in their schools.

Over decades, various studies such as Ocansey (2006), Jackson-Tyree (2012) etc. have been conducted to explore the impact of human activities and the effect of natural phenomena on the environment. Littering is one environmental issue that has been researched extensively, yet the phenomenon persists. Home and school education can be used as platforms to address environmental issues such as littering and global warming, the effects of which are felt locally, nationally and internationally. Litter pose threat to plants and animal life because litter contain injurious objects, such as syringes, broken bottles, plastics, metals and broken glasses that can hurt not only children but adults as well (Ajaegbo, Dashit \& Akume, 2012). In the race for social and economic development, people typically overlook their social responsibilities and neglect to care for nature. Through such negligence they cause environmental damage and pollution (Hsueh \& Su, 2016). Despite numerous studies being conducted in EE, as highlighted below, it appears that environmental campaigns are not yielding the anticipated results in terms of spreading environmental awareness (EA).

Scholars in the field of EE have targeted a variety of aspects of EA: in Vietnam, Hài and Mai (2013) studied EA and the attitudes of Vietnamese consumers towards green purchasing. In Mexico, Jackson-Tyree (2012) undertook a study focusing on the social factors influencing littering in a local urban environment. Coertjens, 
Boeve-de Pauw, De Maeyer and Van Petegem (2010) examined whether schools can make a difference in their learners' environmental attitudes and awareness. Maluleke (2015) examined curriculum policy implementation in the South African context, focusing on EE in the natural sciences. In Kenya, Mutisya and Barker (2011) shared the results of their study on learners' EA and knowledge, and proposed a springboard for action in primary schools. Stanišić and Maksić (2014) investigated EE in Serbian primary schools in respect of challenges and changes in the curriculum, pedagogy and teacher training. Silo (2011) conducted the study to probe participation of learners in waste management activities in selected primary schools in Botswana. Her study was conducted in two phases. Firstly, she analysed learner participation in existing waste management activities to identify tensions and contradictions, and secondly, she expanded learning opportunities for action competence. Parkin, Shackletona and Schudel (2006) explored the influence of school-based Arbour week activities on learners' home-based practices regarding tree planting as a means of urban greening. In addition, Lebeloane (2004) conducted exploratory study to evaluate the "beautification of schools" campaign as an environmental management tool.

The aforementioned scholars all belong to national as well as global communities, and have used common instruments or similar approaches to collect data. Despite this, little research has been done in using the action research (AR) approach in EE to examine learners' awareness of littering. With this study the action research practitioners as researchers aim to bridge that gap, by sharing the experiences of practitioners and learners as coresearchers which were gained through implementing PEAR campaigns specifically aimed at combatting the scourge of littering. PEAR campaign refers to environmental activities conducted in collaboration with coresearchers to raise their awareness of littering and to develop action competence.

This ongoing study intends to respond to the following research question: How can action research influence environmental awareness campaigns aimed at teaching learners about littering?

\section{THEORETICAL FRAMEWORK}

As proposed by developmental action theory (Scruton, 1987), the interaction between AR practitioners and learners as co-researchers should be built on activities that reinforce cooperation, bind people together in pursuit of a common goal, and facilitate a relationship of trust.

\section{The Value and Application of Developmental Action Theory}

Developmental action theory is developed in the $20^{\text {th }}$ century, with industrialised nations representing the most advanced form of society. It categorises other nations in terms of their approximation to this theory. Hence, nations are judged to be either more or less developed, and any efforts made by their respective political, social, educational and economic institutions should be directed towards working their way up the 'development' set goal (Scruton in Bothamley, 2004: 146). South Africa, which is listed among the developing countries, is a member of the BRICS (Brazil, Russia, India, China and South Africa), which is a grouping of emerging economies. It will be the practitioners' acumen as interpretivists to inculcate littering awareness to their learners through participatory paradigms.

\section{Interpretivist and Participatory Paradigms}

By reflecting critically on the status of EE in South Africa, intervention strategies can be devised to help co-researchers consider how they can take action in response to the environmental challenges facing their school and community. The kind of intervention that AR suggests is facilitative, because it relies on co-participatory principles - in other words, securing co-researchers involvement. An intervention becomes much more meaningful and empowering if it is not merely instructive: if co-researchers contribute towards finding solutions to challenges and take action, they have a vested interest in the outcome. Hence, an assumption is made that engaging coresearchers in developmental action theory has the potential to improve their understanding of EA in their lived context. 


\section{CONCEPTUALISATION}

To avoid miscommunication, is it necessary to define or clarify certain terms, and to create a common frame of understanding to make communication more effective (Pudi, 2005). Here, 'littering', 'environmental campaigns' and 'action research' are expanded on.

Littering: In this study, the concept refers to the act of strewing any garbage/waste by discarding and/or misplacing it out in the open; in a field, in the schoolyard or even in a garden. Litter includes food remnants, plastic wrappers, papers and other unwanted items which make a school or home unattractive and untidy. Littered items can pollute the water quality of oceans, rivers, streams, dams and ponds. Many governments are forced to spend huge sums of money to clean contaminated water and polluted land. Litter thus also affects drainage systems as it clogs drains or pipes. Blocked drains system provide excellent breeding grounds for mosquitoes (which spread malaria), besides causing flooding during the monsoon season (Das, 2014). Choked drainage systems cause bad odours which pollute the air and spread disease. Preventing people from littering or controlling litter relies on the effectiveness of both home and school education (Ocansey, 2006).

Environmental campaigns: In a home-based setting, children are exposed to the domestic side of life. To pass on their ecological knowledge to the youth and raise awareness, parents or carers may use hands-on daily activities in combination with different approaches such as stories, proverbs, myths, folktales and rituals (AwuahNyamekye, 2014); shopping, cooking, cleaning and gardening (Kara, Aydos \& Aydin, 2015: 46); hand washing (Mech \& Ojah, 2016); green purchasing (Hài \& Mai, 2013); recycling (Barr, Shaw, \& Coles, 2011); water saving (Keramitsoglou \& Tsagarakis, 2011) and family communication (Dyck, 2012). These approaches are used for the purposes of explaining to people - in particular children - the importance of the environment, and the need to protect and conserve it (Awuah-Nyamekye, 2014: 52). Simsekli (2015) reports that few learners today are unaware of the environmental problems facing the Earth, but their knowledge is limited because teachers emphasise learning 'about', rather than taking action for, the environment (Molapo, Stears \& Dempster, 2014). Larijani (2010: 123) found that the majority of teachers had moderate levels of EA, while Bharambe (2013) noted that their knowledge tends to be academic or book-based. Simsekli (2015: 226) found that learners' attention can be caught via practices involving the environmental problems they face (or may still face) in their region.

Action research: AR is a form of collective self-reflective enquiry which participants undertake in a social situation. The aim of AR is to improve the rationality and justice of participants' own social or educational practices, their understanding of these practices, as well as the context in which the practices are carried out. Participating groups can consist of teachers, learners, principals, parents and other community members - any individuals with a shared concern (Kemmis \& McTaggart, 1988). AR, as a process, allows participants to examine their own educational practice systematically and carefully, using research techniques (Ferrance, 2000). In this study, AR was used as a means of bringing about radical interventions in the participating school. In addition, empowerment and participation are key components of AR (Dyck, 2012). Participation is a key concept in learning (Silo, 2011) and is a central feature of AR (Le Grange, 2009). Therefore, EE according to the critical paradigm should focus on children's empowerment and action and not on the transference of scientific knowledge about ecological crisis (Tsevreni, 2011: $55)$.

\section{RESEARCH PROBLEM}

\section{Aim of the Study}

The aim here was to explore the success of PEAR campaigns on co-researchers' environmental awareness of littering.

\section{Problem Statement}

In recent years, South Africa has seen the emergence of various sectors and public initiatives working towards fostering an environmentally conscious society (Mnisi, 2011). Initiatives include the integration of EE in 
the education system, an Eco-schools programme, the Bontle ke Botho (Clean and Green) campaign and other programmes which address environmental issues. By focusing on littering, it raises awareness of a social issue which requires urgent attention. South Africa's constitution (Republic of South Africa, 1996) stipulates that every citizen has a right to a healthy environment. As Loubser, Swanepoel and Chacko (2001) point out, a clean and healthy environment is, however, dependent on the level of environmental literacy of a nation.

\section{RESEARCH METHODOLOGY}

The research methodology primarily comprises two sections: research design and research methods.

\section{Research Design}

This qualitative study reports on findings derived from a single school using the AR approach. This study employed both interpretivist and participatory paradigms to assess the success of a PEAR campaign against littering.

\section{Research Methods}

\section{Sampling}

The study participants reported on here, were selected based on the researchers' ease of access, through a sampling procedure that is quick to do and cheap to undertake (Maree \& Pietersen, 2008): of the five secondary and 12 primary schools in the target area, the researchers selected a single secondary school due to its close proximity, which enabled them to avoid making significant financial outlays. A single school was selected based on the time frame of the study and the research design. From the group of volunteers (i.e., from the learner population in each of seven classes at this school) the researchers selected two learners randomly, irrespective of age, which made for a manageable population. Thus, 14 learners had been selected through convenience sampling were the eventual co-researchers in this study. Therefore, the results of the study can only be generalised to the participating school under the study because sampling technique used adds to bias towards the study itself.

\section{Data collection instruments}

In qualitative research, words are descriptive tools through which the researcher undertakes transcription and coding processes. An AR design was chosen to evaluate the effectiveness of a PEAR campaign on coresearchers, as it allowed the researchers to take these co-researchers through the processes of planning, action, observation and reflection.

The specific research instruments were deemed relevant to the study: four research instruments participant observation (of daily activities), journal writing (to record what was happening throughout the study), questionnaires (to evaluate attitude, awareness, and perceptions) and pictures which capture a particular situation - were used to collect data. The aim was to understand and explore the implications of PEAR campaigns on coresearchers' awareness of littering. The research instruments helped generate and order information through a triangulation technique, used to ensure the legitimacy of the research findings. As the co-researchers were minors, their identities remained anonymous to ensure confidentiality.

\section{RESEARCH FINDINGS BASED ON OBSERVATIONS}

The researchers analysed data using tables and coding processes, word processors and spreadsheet programs in Microsoft Office. Using tables helped researchers to analyse observed events and simplify our data analysis.

Table 1 presents observed events of the co-researchers celebrating Arbour Day on 1 September 2016. At school, the celebrations were intended to raise co-researchers' awareness of plants, the environment and littering, by linking indoor and outdoor learning processes. School grounds related activities offered opportunities and 


\section{T. A. Mapotse E T. K. Mashiloane/Ameliorate Environmental Education through Action Research}

Table 1. Co-researchers celebrating Arbour Day

\begin{tabular}{|c|c|c|c|}
\hline Coding & Observed & Co-researchers in action & Our opinion/reactions \\
\hline $\begin{array}{l}\text { Environmental } \\
\text { day }\end{array}$ & $\begin{array}{l}\text { Over the years it was } \\
\text { observed that the school } \\
\text { does not celebrate the } \\
\text { environment (except for } \\
\text { Heritage Day, perhaps). }\end{array}$ & $\begin{array}{l}\text { Co-researchers used spades } \\
\text { to dig holes to plant flowers } \\
\text { in and outside the school as } \\
\text { part of celebrating Arbour } \\
\text { Day. }\end{array}$ & $\begin{array}{l}\text { If schools do not celebrate the } \\
\text { environment it denies learners } \\
\text { an opportunity to link } \\
\text { classroom-based knowledge } \\
\text { with an outdoor activity. }\end{array}$ \\
\hline
\end{tabular}

Table 2. Co-researchers collecting garbage from the kitchen

\begin{tabular}{|c|c|c|c|}
\hline Coding & Observed & Co-researchers in action & Our opinion/re \\
\hline EA & $\begin{array}{l}\text { Learners tend to dump } \\
\text { food scraps on the } \\
\text { ground. Food handlers } \\
\text { also throw out scraps and } \\
\text { vegetable waste - there is } \\
\text { a dump site on the terrain. }\end{array}$ & $\begin{array}{l}\text { Co-researchers carry boxes } \\
\text { containing vegetable waste } \\
\text { collected from the school's } \\
\text { kitchen. These materials are taken } \\
\text { from the kitchen on a daily basis, } \\
\text { to make manure for the garden. }\end{array}$ & $\begin{array}{l}\text { The co-researchers seemed to } \\
\text { enjoy this activity, which } \\
\text { empowered them by teaching } \\
\text { them how they could grow } \\
\text { vegetables using food scraps as } \\
\text { compost. }\end{array}$ \\
\hline
\end{tabular}

challenges for constructivist, situated and active learning (Mambinja, 2008: 79). Co-researchers were engaged in active learning processes to stimulate their awareness and thinking process. The majority of co-researchers mentioned that they had never celebrated Arbour Day before, and thanked the researchers for giving them the opportunity to do so. National Arbour Week is potentially a useful vehicle to promote the importance of trees and the benefits that they provide (Parkin et al., 2006: 185) to the co-researchers' awareness and environmental knowledge. One co-researcher mentioned, "The school should encourage learners to bring flowers on this day in order to beautify the school and also this could teach us to know about environmental days". In this school flowers are only planted at administrative block. At this school, it was evident that the focus is on indoor learning, but the outdoor environmental activities seemed to heighten the co-researchers' awareness of environmental issues, amongst them the scourge of litter.

Table 2 presents observed events resulting from co-researchers actions. Co-researchers are engaged PEAR activity to make manure intending to raise their awareness. Comments such as: "besides learning how to make compost I'm also learning ways of saving money as we don't buy manure from the shop but we utilise garbage materials". Another co-researcher stated that "by collecting these waste materials we are also teaching ourselves and food handlers' ways of disposing vegetable waste in an environmentally friendly manner". As it was observed food handlers' throwing waste materials from the kitchen to the dumping site in the schoolyard. This environmental activity aimed to teach the co-researchers about compost making and the three $\mathrm{R}$ (recycle, reuse and reduce), showing them how to reduce litter by re-using organic waste.

In Table 3, co-researchers and the researchers prepared the dump site in the schoolyard before turning it into a vegetable garden. Spades, forks and a wheelbarrows were used to clear the soil and buried some of the waste that decays to fertilise the soil and to soften the soil first before we start cultivating. The activity of planting and nurturing plants aimed to improve the co-researchers' awareness of the natural environment. Research conducted by Cross (2013) revealed that maintaining a school garden and offering environmental lessons in the garden, if possible, have a positive impact on learners' environmental knowledge, attitude and behaviours. The coresearchers' attitudes were transformed in that they were keen to help design the vegetable garden and by maintaining the garden.

In Table 4, co-researchers after the process of turning dump site into vegetable garden. They started planting seedlings and seeds in the furrows after the ground had been prepared for planting. It had taken about three months to prepare and soften the soil because we had to remove hazardous items such as bottles found on this land. The co-researchers showed their interest in and enthusiasm for this fun activity, while nurturing their EA. One co-researcher said that "all teachers and learners must join us, since this garden will contribute more 
Table 3. Co-researchers and researcher preparing the dump site

\begin{tabular}{llll}
\hline Coding & Observed & Co-researchers in action & Our opinion/reactions \\
\hline \multirow{4}{*}{ Garden } & The school do not & Co-researchers used spades, & We observed that engaging co- \\
have a vegetable & forks and a wheelbarrows to & researchers in such an activity seemed \\
& $\begin{array}{l}\text { garden to engage } \\
\text { learners in green } \\
\text { activities. }\end{array}$ & $\begin{array}{l}\text { prepare the dump site into } \\
\text { garden. }\end{array}$ & $\begin{array}{l}\text { to have conscientise them to utilize } \\
\text { dump site for environmental activities. }\end{array}$ \\
\end{tabular}

Table 4. Co-researchers cultivating seed and seedlings

\begin{tabular}{llll}
\hline Coding & Observed & Co-researchers in action & Our opinion/reactions \\
\hline & Majority of co-researchers & In the course of cultivation & The process of cultivating seeds \\
& at home they don't have & process co-researchers created & and seedlings seemed to have \\
Cultivate & $\begin{array}{l}\text { garden, suggesting they } \\
\text { do not know how to }\end{array}$ & rows and furrows first in order & heighten co-researchers \\
& to cultivate seeds and & knowledge about vegetable \\
& sultivate. & & $\begin{array}{l}\text { garden and types of seeds and } \\
\text { seedlings. }\end{array}$ \\
\hline
\end{tabular}

Table 5. Co-researcher picking up litter

\begin{tabular}{llll}
\hline Coding & Observed & Co-researchers in action & Our opinion/reactions \\
\hline \multirow{4}{*}{ Campaign } & It was observed during & Co-researchers cleaned up & Litter pick-up activity was \\
& breaks and after school & rubbish and placed inside the & successful conducted and it \\
& learners toss trash on & rubbish bags and these plastics & appeared to have effect on other \\
& the ground. & are put inside the bin. & $\begin{array}{l}\text { learners as well, as bins were } \\
\text { used. }\end{array}$ \\
\hline
\end{tabular}

vegetable especially in the school kitchen". Another co-researcher mentioned that "this garden, besides producing vegetables, also makes us to respect the environment and learn how to plant seedlings and seeds because at home some of us don't have vegetable garden". This shows the collaborative nature of the project, and planning for a sustainable future (i.e., there will always be vegetables for use in the kitchen).

In Table 5, learners during breaks drops litter on the ground and the food scrap lying on the ground attract birds in the school. Co-researchers engaged in picking up litter to keep the terrain clean and take responsibility for their environment. During this activity co-researcher pointed out that "all teachers and learners should be with us in keeping the school clean and maybe learners will stop littering". The school does not have a duty roster which assigns learners or teachers to pick up litter on the grounds. As a result, learners continue to litter as they see fit. Perhaps degradation was caused by lack of discipline, respect and negligence in schools (Msezane, 2014).

The co-researchers were also engaged in planting trees presented in Table 6 . The aim here was to conscientise them about the role that trees play on people's lives through gaseous exchange. The trees provide people with oxygen while people provide trees with carbon dioxide. Moreover, trees provide fruit, shade, windbreaks, medicine etc. (Parkin et al., 2006). The trees were donated by a company called Eco-cycle, to celebrate Earth Day on 22 April 2016. Learners showed interest during the plantation as others asked their peers to take pictures while they were planting and observations are logged in my journal. After helping to plant the trees, the co-researchers watered them, using buckets to do so. The emphasis was on saving water and using it responsibly. The co-researchers subsequently gave the trees names, such as 'hug me' and 'ngwana waka' (my baby), which revealed their love of the trees.

\section{ANALYSIS OF THE QUESTIONNAIRE}

Co-researchers completed two sets of the questionnaires at the beginning and end of the study with the intention of comparing outcomes after interventions has taken place to consolidate other data collection methods. 


\section{T. A. Mapotse E T. K. Mashiloane/Ameliorate Environmental Education through Action Research}

Table 6. Co-researchers nurturing trees

\begin{tabular}{|c|c|c|c|}
\hline Coding & Observed & Co-researchers in action & Our opinion/reactions \\
\hline Awa & $\begin{array}{l}\text { Trees were donated } \\
\text { to the school to } \\
\text { celebrate Earth Day as } \\
\text { the school is lacking } \\
\text { trees. }\end{array}$ & $\begin{array}{l}\text { Learners used spades to dig } \\
\text { holes on the ground to plant } \\
\text { the trees and watered the trees } \\
\text { afterwards. }\end{array}$ & $\begin{array}{l}\text { Learners were happy to celebrate } \\
\text { Earth Day with the teachers and } \\
\text { members of the Eco-cycle and their } \\
\text { enjoyment implied that their } \\
\text { awareness was raised. }\end{array}$ \\
\hline
\end{tabular}

Fourteen co-researchers completed first set of the questionnaire and second set the number of co-researchers that completed the questionnaire previously declined to nine due to withdrawals.

\section{School Environmental Policy}

On the pre analysis indicated co-researchers response, $28.57 \%$ yes; $21.43 \%$ no and $50 \%$ I do not know. This indicated that the school do not have environmental policy. In the post analysis, all the co-researchers $(100 \%)$ indicated that the school has an environmental policy. The policy was designed as part of interventions and this is key in any AR project to come up with solutions. Again $57 \%$ on the post analysis indicated that the policy is partially practised. This showed improvement as the school now has a policy.

\section{Environmental Awareness}

Majority of co-researchers revealed that littering is an environmental problem as indicated on pre analysis $(79 \%)$ and post analysis (100\%). This finding concurs with the following studies, Kärkkäinen, Haukipuro, Rummukainen, Keinonen and Simola (2013) learners highlighted littering as a national and global environmental problem. In addition, Hartley, Thompson and Pahl (2015) found that children recognise that marine litter is an important problem that has a negative impact on the environment, coastal industries, and human health. Additionally, learners from an environmentally polluted area are more aware and have more positive attitudes than their contemporaries from a different area (Olufemi, Mji \& Mukhola, 2013). Understandably, awareness of the problem results in attempts to solve the issue and some of the attempts included recycling waste materials to make manure for the garden.

On the pre-analysis (64\%) of co-researchers indicated that they would leave littered items on the ground and post-analysis $(44 \%)$ shows decline and their behaviour seemed to have changed. Interestingly, co-researchers on pre-analysis (79\%) and post-analysis $(67 \%)$ indicated that they do not litter. They put their food wrappers inside litterbins or school bag. This showed good environmental behaviour since visibility of littered items on the ground will be minimal. The ensuing section discusses and summarise PEAR campaigns conducted with co-researchers.

\section{PROGRESSIVE ENVIRONMENTAL ACTION RESEARCH SPIRAL CYCLES}

In this section, researchers discuss campaigns conducted in collaboration with co-researchers through cyclic process displayed on Figure 1. Several cyclic PEAR campaigns were undertaken with the co-researchers aimed at addressing littering and, along the way, improving co-researchers' EA, so as to effect a change in attitude. The co-researchers were engaged in numerous PEAR campaigns through AR spiral cycles, which included setting up a vegetable garden, planting seedlings and seeds, picking up litter, making manure, planting trees and designing school environmental policy. These campaigns discussed different aspects such as exploration of soil, wastes, and environmental monitoring tools.

On the first campaign, that is cycle one, as illustrated on Figure 1, co-researchers were engaged in the exploration of the soil in preparation for vegetable garden and celebration of Arbour Day. The school did not have vegetable garden and dumping site was identified within the schoolyard to start the garden. The land was prepared for months by removing hazardous items and buried other items to fertilise the soil. Afterwards, co-researchers irrigated the land in preparation for cultivation. Co-researchers successfully turned dumpsite into vegetable 


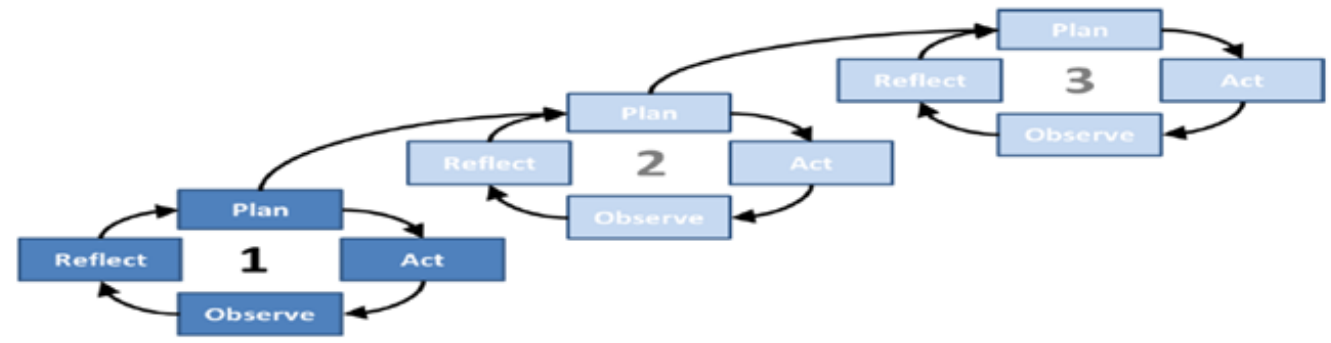

Figure 1. PEAR spiral cycles with co-researchers (adapted from Rose, Spinks \& Canhoto 2015)

Table 7. Summarised co-researchers' campaigns per cycle

\begin{tabular}{ll}
\hline PEAR CYCLE & CO-RESEACHERS' CAMPAIGNS \\
\hline Spiral Cycle 1 & Soil exploration and Arbour Day celebration \\
\hline Spiral Cycle 2 & Reuse and recycling of waste materials \\
\hline Spiral Cycle 3 & Introduction of environmental monitoring tools \\
\hline
\end{tabular}

garden. Co-researchers once more celebrated Arbour Day at school by planting flowers. In turn, the initiative beautified the school and raised their awareness of the importance of soil and environmental days.

Figure 1 displayed second PEAR spiral cycle campaign to raise co-researchers' awareness of wastes. In this cycle, co-researchers collected vegetable waste materials from school kitchen to make manure for the garden. This campaign conducted in this cycle raised co-researchers' awareness towards wastes with reference to the success of the activity.

In Figure 1 cycle three, co-researchers introduced environmental monitoring tools which included litter pick up campaign to encourage their peers to keep the school clean. Subsequently, co-researchers wrote the school environmental policy since the school did not have one. The policy intended to put into action of tackling littering in the school. Table 7 summarises co-researchers' campaigns per spiral cycle, which is developed from Figure 1.

These outdoor environmental campaigns promoted environmental learning opportunities for coresearchers because classroom activities limit learners' environmental learning (Sehlola, 2007). This hands-on approach is vital to any AR undertaking and infused action competence. Action competence emphasised learnerled activities mediated by deliberative co-engagement that highlight respect for difference (plural dispositions) in democratic societies (O'Donoghue, 2007: 147). This approach increased learning opportunities of co-researchers throughout as they were not mere participating but taking action to curb littering in the school through collaborative engagement including planning, acting, observing and reflecting. Competence approach points to democratic, participatory and action-oriented teaching-learning that can help learners develop their ability, motivation and desire to play an active role in finding democratic solutions to problems and issues connected to sustainable development (Mogensen \& Schnack, 2010).

Co-researchers were provided with opportunities to take action to influence real life environmental issues that they were confronted with daily, as part of their action-oriented activities. Hence, by engaging co-researchers in identifying problems and coming up with action-oriented solutions, they became co-catalysts for change in the school environment (Silo \& Mswela, 2016).

\section{DISCUSSION AND RESULTS}

Littering is an environmental issue which involves the misplacing of items or the deliberate discarding of objects once they are no longer useful. In many instances such items (papers, plastics and cans) can be recycled. As it was indicated above by the learners that "food is tasteless" hence discard it on the ground polluting the general aesthetic of the school. As a result, co-researchers addressed discarding of such items on the ground through litter 
campaign and turning waste materials into manure to conscientise learners towards littering. Thus, in turn reduce littering in the school.

Msezane and Mudau (2014) study found that learners continued to litter even after participation in EE as an extra mural activities. This suggests that activities that were conducted with learners infused knowledge based hence had minimal impact on the learners. The effectiveness of EE campaigns/activities should incorporate knowledge based and action orientated to conscientise learners towards littering. As in this study, co-researchers were engaged in exploration of soil, wastes, and environmental monitoring tools. These campaigns infused both knowledge and action.

Furthermore, this study noted that a lack of environmental programmes in the school is also to blame for the fact that children often unwittingly litter or pollute their environment. Consequently, school environmental policy was designed as part of environmental tools to control learner littering behaviour in the school. This improved co-researchers' awareness of littering as it was indicated on the questionnaire that littering is an environmental issue and they put garbage in the litterbins or their school bags. A co-researcher further indicated, "I used to litter school ground but since we have started with campaigns I am no longer littering". This was indication that PEAR campaigns had impact on the co-researchers' awareness of littering. Our fragile Earth is threatened by, amongst others, littering and many other harmful human actions. Activities which have a positive impact on the environment include throwing garbage in garbage cans or recycling recyclables. Through environmentally sound activities, such as picking up litter and establishing vegetable gardens, we can protect our fragile environment.

Moreover, Dyck (2012) study found that involvement in the program led participants to engage in environmentally responsible action and helped them to identify areas that they wished to take action on in the future. In this case studied school co-researchers recycled waste materials to make manure with the intention of reducing littering. Utilisation of waste materials had impact on the co-researchers as indicated above that they learnt ways to save money and environmentally friendly ways of disposing wastes. Cross (2013: 2) states that one way to connect young people to the environment may be to create a school garden, where learners may be responsible for designing, planting, maintaining and harvesting vegetables. Exposing them to gardening at school might be one avenue through which to cultivate future generations of environmental stewards. Children cherish hands-on activities, which they may remember for the rest of their lives. Kolb (1985: 267) attests that we tend to understand that which we are involved in.

Outdoor learning activities promote hands-on tasks such as planting flowers and recycling organic material. Hands-on activities make learning fun for children and increase their interest the subject at hand. During plantation of trees celebrating Arbour Day, co-researchers indicated that school must encourage learners to bring flowers to beautify the school and another co-researcher indicated, "It was refreshing to engage in this activity and being away from the classroom. I wish the school could continue to celebrate environmental days". This was indication that a PEAR campaign has effect on co-researchers. Therefore, learners' interest in, and excitement about, what they are learning are two of the most important factors in education (Woolfolk, 2010: 394).

This scholar Silo (2011) conducted her study in two phases. The first phase of the study revealed that participation of learners in waste management activities was largely teacher-directed. Second phase, the study showed that if learners' participation is taken seriously, and if opportunities for dialogue exist between teachers and learner, positive changes for a healthier environment can be created in schools. In this study, co-researchers were in the centre of the campaigns addressing litter issue in the school in collaboration with the researchers. This process mediated teacher-centred approach to co-researchers-researchers engagement. Co-researchers identified littering as an environmental issue in turn provided solutions to the problem such as designing school environmental policy. Subsequently, the action model that evolved through this research proved to be a tool for children to develop their participatory capacities and, especially, to gain self-confidence about their perceptions of their environment and understandings of the local issues facing them as children and adults in the future (Tsevreni, 2011). 


\section{CONCLUSION}

Teachers and learners could use PEAR campaigns to address environmental issues such as littering. PEAR campaigns could start in the classroom, with learners taking turns to sweep the class or pick up litter. However, teachers should monitor all activities. The conclusion drawn here is that AR can be used as a tool to raise learners' awareness of the environment. As Cross (2013) found, the use of a school garden for environmental lessons proved effective in raising awareness amongst learners.

A dirty or litter-strewn environment encourages learners to litter and portrays a negative image of the school (Makonya, 2004). Schools with a poor, unwelcoming exterior promote neither attendance nor attachment, because children and teachers want to learn and work in clean surroundings (Doan \& Jablonski, 2012).

Most schools in this country punish misbehaving learners by forcing them to clean the terrain (Msezane, 2014; Sehlola, 2007); hence, learners have a negative attitude towards keeping their environment clean because grounds staff and volunteers will clean up after them. The sooner this practice stops, of punishing learners by making them do manual labour, the sooner learners' EA activities will be taken seriously and will flow from a willingness to keep their surroundings clean.

The aim of this study was to engage co-researchers, through AR circular activities of observation, planning, action and reflection of their daily activities, to raise an awareness of littering. Daily hands-on environmental activities and/or practices at home or at school could be the answer in addressing the problem of littering, provided activities are implemented through AR. Activities such as picking up papers could be utilised to conscientise learners and raise awareness of the harmful effects of littering. Eventually, small acts will work together to improve everyone's environmental literacy.

\section{REFERENCES}

Ajaegbo, E., Dashit, S. I., \& Akume, A. T. (2012). The determinants of littering attitude in urban neighbourhoods of Jos. Jorind, 10(3), 82-94.

Awuah-Nyamekye, S. (2014). Indigenous ways of creating environmental awareness: A case study from Berekum Traditional Area, Ghana. Journal for the Study of Religion, Nature E Culture, 8(1), 46-63.

Barr, S., Shaw, G., \& Coles, T. (2011). Sustainable lifestyles: Sites, practices, and policy. Environment and Planning, 43(12), 3011-3029.

Bharambe, I. T. (2013). Study of environmental awareness among secondary school students. Edubeam Multidisciplinary-Online Research Journal, 1(1), 1-11.

Bothamley, J. (2004). Dictionary of theories. New York: Barnes \& Noble Books.

Budvytyte, A. (2011). Environmental education at secondary school system in Lithuania: Using Šilute as a case. MEd dissertation. Lithuania: Lund University.

Coertjens, L., Boeve-de Pauw, J., De Maeyer, S., \& Van Petegem, P. (2010). Do schools make a difference in their students' environmental attitudes and awareness? Evidence from PISA 2006. International Journal of Science and Mathematics Education, 8(3), 497-522.

Cross, B. A. (2013). The impact of a school garden and environmental education on the environmental awareness of fifth graders. MA dissertation. Louisiana: Southeastern Louisiana Hammond University.

Das, M. (2014). Secondary school students' awareness on plastic pollution and environmental education: A study. Global Online Electronic International Interdisciplinary Research Journal, 2(5), 10-25.

Doan, K., \& Jablonski, B. (2012). In their own words, urban students make suggestions for improving the appearance of their schools. Urban Review Journal, 44, 649-663.

Dyck, S. L. (2012). Engaging families in environmental education: How action, critical thinking, and social learning can foster change. Environmental Education Research, 19(2), 254-255.

Ferrance, E. (2000). Action research. Virgin Island: Brown University. 
Hài, H. V., \& Mai, N. P. (2013). Environmental awareness and attitude of Vietnamese consumers towards green purchasing. Journal of Economics and Business, 29(2), 129-141.

Hartley, B. L., Thompson, R. C., \& Pahl, S. (2015). Marine litter education boosts children's understanding and selfreported actions. Marine Pollution Bulletin, 90(1), 209-217.

Hsueh, S. L., \& Su, F. L. (2016). Critical factors that influences the success of cultivating seed teachers in environmental education. Eurasia Journal of Mathematics, Science \& Technology Education, 12(11), 2817-2833.

Jackson-Tyree, J. E. (2012). Social factors influencing littering in an urban Mexican environment. MSc dissertation. Purdue: Purdue University.

Kara, E. G., Aydos, E. H., \& Aydin, Ö. (2015). Changing preschool children's attitudes into behaviour towards selected environmental issues: An action research study. International Journal of Education in Mathematics, Science and Technology, 3(1), 46-63.

Kärkkäinen, S., Haukipuro, L., Rummukainen, A. M., Keinonen, T., \& Simola, H. (2013). Environmental responsibility: A case study among sixth graders. Problems of Education in the 21st Century, 54, 22-38.

Kemmis, S., \& McTaggart, R. (1988). The action research planner. Victoria, Australia: Deakin University Press.

Keramitsoglou, K. M., \& Tsagarakis, K. P. (2011). Raising effective awareness for domestic water saving: Evidence from an environmental educational programme in Greece. Water Policy, 13(6), 828-844.

Kolb, D. (1985). Learning styles inventory. Boston: McBer \& Company.

Komane, F. N. (2005). The assessment of environmental awareness of the secondary school learners in the Mabopane District. MSc dissertation. Potchefstroom: North-West University.

Larijani, M. (2010). Assessment of environmental awareness among higher primary school teachers. Journal of Human Ecology, 31(2), 121-124.

Le Grange, L. (2003). Opportunities that the South African OBE curriculum framework provides for addressing environmental concerns. Education as Change, 7(1), 34-49.

Le Grange, L. (2009). Participation and participatory action research (PAR) in environmental education processes: for what are people empowered? Australian Journal of Environmental Education, 25, 3-14.

Lebeloane, L. D. M. (2004). The "beautification of schools" campaign as an environmental management tool. MEd dissertation. Potchefstroom: North-West University.

Loubser, C. P., Swanepoel, C. H., \& Chacko, C. P. C. (2001). Concept formulation for environmental literacy. South African Journal of Education, 21(4), 317-323.

Makonya, W. (2004). A study of litter problems in selected secondary schools in Bulawayo. MEd dissertation. Pretoria: University of South Africa.

Maluleke, H. M. (2015). Curriculum policy implementation in the South African context, with reference to environmental education within the natural sciences. DEd thesis. Pretoria: University of South Africa.

Mambinja, S. (2008). School grounds as a place for environmental learning in the life skills learning programme. MEd dissertation. Grahamstown: Rhodes University.

Maree, K., \& Pietersen, J. (2008). Sampling. In K. Maree (Ed.), First steps in research (2nd ed.), pp. 171-181. Pretoria: Van Schaik.

Mech, K., \& Ojah, J. A. (2016). Study on the awareness and practices of hand washing amongst mothers of underfive children in the slums of Guwahati city. Journal of Evidence Based Medicine and Healthcare, 3(24), 10751078.

Mnisi, N. D. (2011). Environmental perception, awareness and behaviour of households in the Johannesburg metropolitan area. MSc dissertation. Johannesburg: University of Johannesburg.

Mogensen, F., \& Schnack, K. (2010). The action competence approach and the 'new' discourses of education for sustainable development, competence and quality criteria, Environmental Education Research, 16(1), 59-74

Molapo, L., Stears, L., \& Dempster, E. (2014). Does formal environmental knowledge inform the everyday practices of senior secondary Biology learners in Lesotho? Southern African Journal of Environmental Education, 30(1), 118-127. 
Msezane, S. B. (2014). An exploration of the impact of environmental education innovation on students in sustaining land resources: A case of Mkhondo village. MEd dissertation. Pretoria: University of South Africa.

Msezane, S. B., \& Mudau, A. V. (2014). Reconnoitering the stimulus of environmental education in reducing improper solid waste disposal: a case of St Marcia School in the Mkhondo village in Mpumalanga in South Africa. Journal of Human Ecology, 48(3), 367-374.

Mutisya, S. M., \& Barker, M. (2011). Pupils' environmental awareness and knowledge: A springboard for action in primary schools in Kenya's Rift Valley. Science Education International, 22(1), 55-71.

Obong, L. B., Okey, S. M., Aniah, E. J., \& Okaba, L. A. (2010). Strategies for school environmental management in Nigerian secondary schools: A case of Calabar, Nigeria. International Education Studies, 3(1), 96-205.

Ocansey, A. (2006). Attitude of JSS 3 students in the Cape-Coast municipality of Ghana towards littering. MEd dissertation. Cape Coast: University of Cape Coast.

O'Donoghue, R. (2007). Environment and sustainability education in a changing South Africa: A critical historical analysis of outline schemes for defining and guiding learning interactions. Southern African Journal of Environmental Education, 24, 141-157.

Olufemi, A. C., Mji, A., \& Mukhola, M. S. (2013). Establishing differences with respect to the levels of awareness and attitudes of learners about environmental pollution: A comparative study of South African provincial secondary school types. Journal of Educational Studies, 12(1), 33-45.

Parkin, F., Shackleton, C., \& Schudel, I. (2006). The effectiveness of schools-based National Arbor Week activities in greening of urban homesteads: A case study of Grahamstown, South Africa. Urban forestry $\mathcal{E}$ urban greening, 5(4), 177-187.

Pudi, T. I. (2005). Educator roles for technology education teacher-educator. Africa Education Review, 34(1), 147-167.

Republic of South Africa. (1996). Constitution of the Republic of South Africa, Act 108 of 1996. Pretoria: Government Printer.

Rose, S., Spinks, N., \& Canhoto, A. I. (2015). Management research: Applying the principles. New York: Routledge.

Scruton, R. (1987). Laughter. In J. Morreall (Ed.). The philosophy of laughter and humour, pp. 156-171. New York: State University of New York Press.

Sehlola, M. S. (2007). A case study of the integration of environmental learning in the primary school curriculum. MEd dissertation. Pretoria: University of Pretoria.

Sethusha, M. J., \& Lumadi, M. W. (2013). Grade six learners' perceptions of environmental awareness: A human ecological support programme. Journal of Human Ecology, 42(2), 113-123.

Silo, N. (2011). Exploring opportunities for action competence development through learners' participation in waste management activities in selected primary schools in Botswana. DEd thesis. Grahamstown: Rhodes University.

Silo, N., \& Mswela, N. (2016). Creating healthy school environments through children-an action competence approach. European Journal of Education Studies, 2(6), 46-62.

Simsekli, Y. (2015). An implementation to raise environmental awareness of elementary education students. Procedia-Social and Behavioural Sciences, 191, 222-226.

Stanišić, J., \& Maksić, S. (2014). Environmental education in Serbian primary schools: Challenges and changes in curriculum, pedagogy, and teacher training. Journal of Environmental Education, 45(2), 118-131.

Tsevreni, I. (2011). Towards an environmental education without scientific knowledge: an attempt to create an action model based on children's experiences, emotions and perceptions about their environment. Environmental Education Research, 17(1), 53-67.

Woolfolk, A. (2010). Educational psychology (11th Ed.). Boston: Pearson.

\section{http://www.ejmste.com}

